\title{
Bacterial Anti-Adhesion of Coated and Uncoated Thin-Film- Composite (TFC) Polyamide (PA) Membranes
}

\author{
Juha Nikkola a, ${ }^{\mathrm{*}}$, Hanna-Leena Alakomi ${ }^{\mathrm{a}}$ and Chuyang Y. Tang ${ }^{\mathrm{b}}$ \\ ${ }^{a}$ VTT Technical Research Centre of Finland, Box 1000, 02044 Espoo, Finland \\ ${ }^{b}$ Department of Civil Engineering, The University of Hong Kong, Pokfulam, Hong Kong
}

\begin{abstract}
This study investigates the bacterial anti-adhesion performance of uncoated and coated reverse osmosis (RO) membranes. All the membranes were commercially available fully-aromatic thin-filmcomposite (TFC) polyamide (PA) membranes. Two of the TFC PA membranes (SW30 and BW30) were coated using polyvinyl alcohol (PVA) coating, while the other three membranes (LE, XLE and NF90) were uncoated. Among the characterised TFC PA membranes, the PVA coated were more hydrophilic and their surface energy was higher in comparison to uncoated. In addition, the PVA coated membranes had lower surface roughness. AFM interaction force measurement demonstrated higher repellence performance for the more polar surface. Bacteria attachment test showed differences between the coated and the uncoated membranes. Indeed, the increase in hydrophilicity and surface polarity showed decrease in the attachment of Pseudomonas aeruginosa cells. Moreover, the results demonstrated that the surface polarity showed better correlation with the attachment of the bacteria. In addition, the type of the surface roughness may somehow contribute to the bacteria repellence.
\end{abstract}

Received on 28-02-2014 Accepted on 24-04-2014 Published on 25-06-2014

Keywords: Thin film composite (TFC) polyamide (PA) membrane, polyvinyl alcohol (PVA), surface energy, topography, biofouling.

\section{INTRODUCTION}

The biofilm growth on membrane has an effect on the membrane separation efficiency as well as energy consumption. The membrane permeability declines resulting unstable water flux behaviour and therefore, feed pressure should be increased for the stabilization of the process [1].

Biofouling is generally initiated by adhesion and accumulation of the planktonic microorganisms which follows primary colonization and logarithmical growth [2]. Furthermore, a number of the microorganisms, such as bacteria, can be detected within the network of extracellular polymer substances (EPS).

Membrane surface properties such as, hydrophilicity, surface roughness and surface charge, as well as surface chemistry play key roles in the reducing of the fouling [3-5]. Modern thin film composite (TFC) membranes, used in the seawater and brackish water reverse osmosis (RO) treatment, typically consist of polyamide (PA) as a selective layer and polysulfone (PSf) as a support layer [6-7]. Furthermore, it has been shown that some of the commercial TFC PA

"VTT Technical Research Centre of Finland; Biologinkuja 7, 02044 Espoo, Finland; Tel: (358) 207223672; Fax: (358) 207223498;

E-mail: juha.nikkola@vtt.fi membranes are coated by additional coating layer to increase their surface hydrophilicity [8].

Several groups have studied the effects of the surface properties on the colloidal and organic fouling tendency of the commercial RO membranes [1, 3, 4, 7, 9-11]. Moreover, the biofouling tendency has been studied as well [12-14]. However, a few studies have concentrated on the interaction between bacteria and surface properties of RO membrane in the biofilm formation [15-18]. The previous studies have revealed the differences in the bacterial anti-adhesion performance between various different polymeric RO membranes. These studies have suggested that both hydrophilic and hydrophobic membrane surface may decrease the bacteria attachment [19]. Indeed, this indicates that the membrane surface chemistry have the dominant effect on the attachment of bacteria. However, there is lack of experiments, which focus solely on fully-aromatic TFC PA membranes. In addition, the bacteria attachment on coated TFC PA membranes has not been studied extensively.

This study aimed to improve the understanding of the biofouling tendency of the uncoated and coated fully-aromatic TFC PA membranes. We studied the effect of hydrophilicity, surface energy and surface morphology on anti-adhesion of Pseudomonas aeruginosa cells. Furthermore, atomic force 
microscope (AFM) interaction force measurement contributed the understanding of the anti-adhesion performance.

\section{EXPERIMENTAL}

\subsection{Membrane Materials}

Five commercially available TFC PA membranes (SW30HR, BW30, LE, XLE and NF90) were used in the current study as test materials. The type of these membranes are seawater RO membrane (SW3OHR), brackish water RO membranes (BW30, LE, XLE) or nanofiltration (NF90). According to previous investigations, all the membranes have fully aromatic PA as selective layer. Furthermore, SW3OHR and BW30 are coated using polyvinyl alcohol (PVA) coating, while LE, XLE and NF90 are uncoated membranes [8]. The membranes were purchased from DOW FilmTec.

\subsection{Characterisation of the Surface Properties}

The surface morphologies of the selected membranes were characterized with a JEM 1230 transmission electron microscope (TEM) at an acceleration voltage of $80 \mathrm{kV}$ according to Tang et al. [20]. Briefly, MilliQ water cleaned virgin membrane sample were dehydrated by ethanol and embedded in an aromatic acrylic LR White resin (Polyscience, Warrington, PA, polymerized at $48^{\circ} \mathrm{C}$ for 3 days). Thin TEM sections less than $100 \mathrm{~nm}$ thick were cut and imaged in the TEM without any staining.

The surface topographies of the membranes were characterized using non-contact mode atomic force microscopy (NC-AFM). It has gained little attention compared to tapping mode [28]. However, the NC-AFM is recommended when studying sensitive and soft polymeric surfaces. The NC-AFM analysis was performed by using Park Systems XE-100 AFM equipment with cantilever 905MACTA (purchased from ST Instruments B.V.). In a typical experiment the topography was analysed from the area $5 \times 5$ $\mu \mathrm{m}^{2}$ by using scan rate $0.4-0.6 \mathrm{~Hz}$.

Contact angles were measured using Optical Tensiometer Theta T200 device (Attension, Biolin Scientific). The measurements were made within a controlled atmosphere ( $\mathrm{RH} 50 \%$, temperature $23{ }^{\circ} \mathrm{C}$ ). Water contact angle values, expressed as ${ }^{\circ}$, are presented at the time of $30 \mathrm{~s}$ from the moment the drop contacts the surface. Results are given as an average of five parallel measurements. Surface energy values were obtained by measuring the contact angle of three different probe liquids, including water $\left(\mathrm{H}_{2} \mathrm{O}, \mathrm{Y}=72.80\right.$ $\mathrm{mN} / \mathrm{m})$, di-iodomethane $\left(\mathrm{CH}_{2} \mathrm{l}_{2}, \mathrm{Y}=50.80 \mathrm{mN} / \mathrm{m}\right)$ and formamide $\left(\mathrm{CH}_{3} \mathrm{NO}, \mathrm{Y}=58.20 \mathrm{mN} / \mathrm{m}\right)$. The total surface energy values, as summary of polar and dispersive surface energies, were determined from the measured contact angle data using the Fowkes theory [21].

\subsection{AFM Interaction Force Measurement}

AFM interaction force measurement is a useful method to measure the interaction force between a cantilever probe (foulant surrogate) and a membrane surface [22-24]. In the current study, AFM interaction force measurement between a colloidal cantilever tip and membrane surfaces was performed according to Tang et al. [22]. Briefly, the device used was a MultiMode $\AA$ SPM equipped with a $J$ type piezoelectric scanner and a NanoScope ${ }^{\circledR}$ IV controller. A 5 $\mu \mathrm{m}$ borosilicate microsphere was attached to tip of the AFM cantilever (Bioforce Nanoscience). The microsphere was functionalized with carboxylic groups $(-\mathrm{COOH})$ to mimic the functional group of a typical organic foulants such as humic acid, proteins or bacteria. AFM force measurement was conducted in a liquid cell under contact mode by using a spring constant of $0.12 \mathrm{~N} / \mathrm{m}$.

\subsection{Attachment of Bacteria}

Biofilm formation was demonstrated by analysing the attachment of $P$. aeruginosa on uncoated and coated membranes. P. aeruginosa is Gram-negative, aerobic, rodshaped bacterium, which is widely used as the model microbe for biofilm formation study [12, 14, 15]. Therefore, $P$. aeruginosa was selected as model bacterium in our study to provide comparable data related to the attachment of bacteria.

Bacteria attachment test was conducted by submerging the membranes $(\varnothing 4.7 \mathrm{~cm})$ in bacterial suspension consisted of standard seawater ASTM D1141-98 (2008) [25]. Furthermore, the suspension was inoculated with overnight culture of $P$. aeruginosa (VTT E-96726) cultivated in $37^{\circ} \mathrm{C}$ Trypticase soy agar (TSA) broth solution, harvested by centrifugation (3000 rpm, $10 \mathrm{~min})$ and washed with phosphate-buffered saline (PBS) $(10 \mathrm{mM})$. The cell density

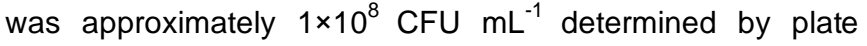
count on TSA $\left(37^{\circ} \mathrm{C}, 1 \mathrm{~d}\right)$. The exposure of membranes was conducted in a rotary shaker $(75 \mathrm{rpm})$ at room temperature for $1 \mathrm{~d}$. The number of adhered cells on the membranes was determined after swabbing by plate count on TSA $\left(37^{\circ} \mathrm{C}, 1 \mathrm{~d}\right)$. It was aimed to describe the anti-adhesion performance. Results are presented as colony forming units per membrane area $\left(\mathrm{CFU} \mathrm{\textrm {cm } ^ { - 2 }}\right.$ ). Three replicate membrane samples were examined for each membrane type.

\section{RESULTS AND DISCUSSION}

\subsection{TEM Micrographs}

TEM imaging was used to the compare the surface morphology of two selected membranes BW30 and NF90. Figure 1 presents TEM micrographs of BW30 and NF90. Both membranes had ridge-valley-structure that is typical for TFC PA membranes. TEM images revealed clearly the characteristic PSf and PA layers [26]. However, the comparison of the TEM micrographs revealed some differences between the membranes. NF90 membrane showed rougher surface and less homogeneous peak-tovalley topography. In contrast, BW30 membrane showed homogenous topography with light coloured areas in the 


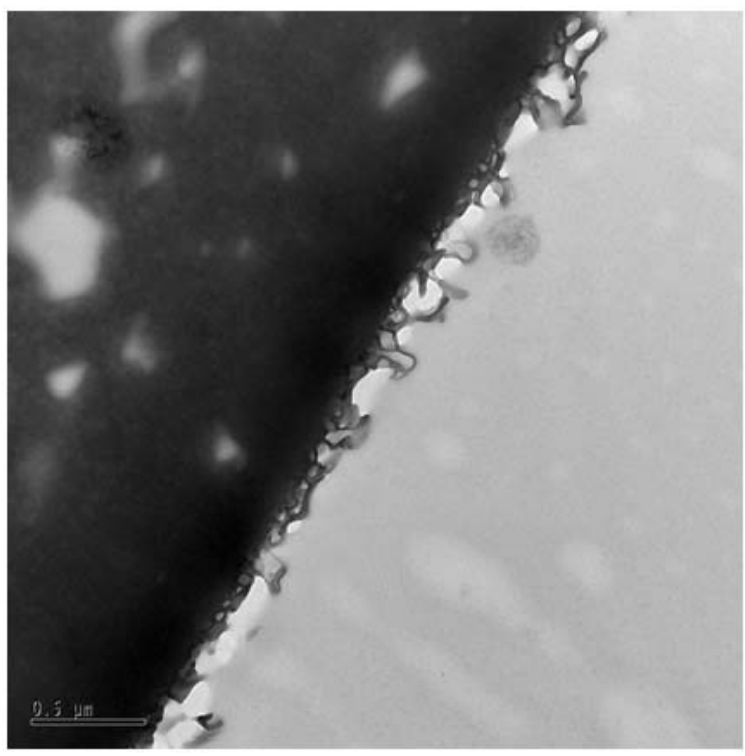

(a) BW30

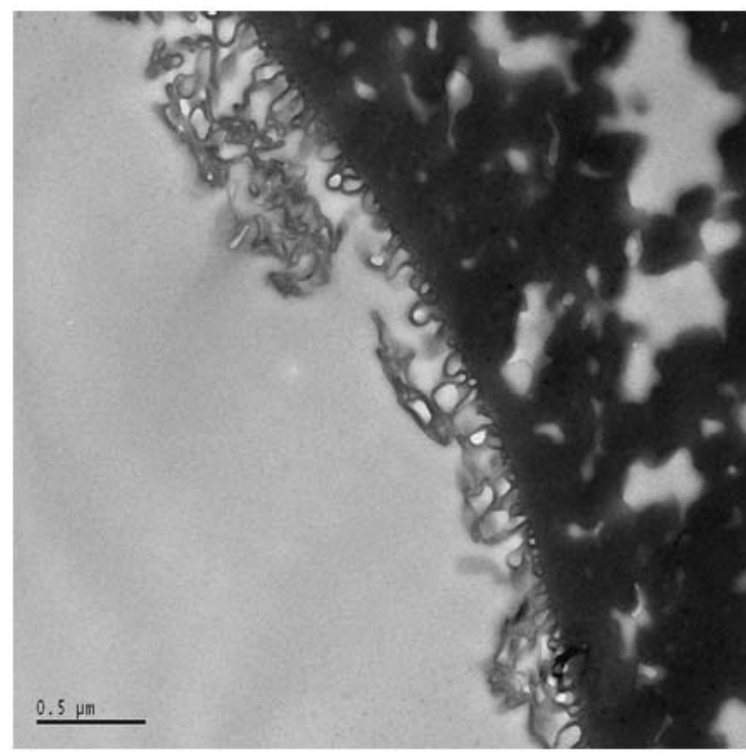

(b) NF90

Figure 1: The TEM micrographs of the a) BW30 and b) NF90 membranes.

valleys of the PA layer. The light coloured areas have been previously concluded as additional polymeric polyvinyl alcohol (PVA) coating layer $[8,26]$.

\subsection{AFM Surface Topography}

Figure 2 presents the AFM images of the TFC PA membranes. The AFM images showed the typical ridge-andvalley surface texture of PA TFC membrane [8]. Furthermore, those revealed the nodular topography of typical polymeric membrane [24]. AFM images of SW30HR and BW30 showed nanostructured topographies with pattern of ridges and nanosized valleys with the diameter of typically $100-200 \mathrm{~nm}$. The topography of LE membrane (image c) was almost identical, however the size of the ridges and the valleys were somewhat larger compared to BW30 and SW30HR membranes.

The topographies of XLE and NF90 membranes differed clearly from BW30, SW3OHR and LE membranes. Their ridges were thicker as well as the length of the valleys were longer with diameter 300-500 nm In addition, it was observed more dominant number of peaks than for XLE and NF90 membranes. These results are in good agreement with TEM observations (Figure 1) that NF90 had much more extensive roughness structures and more dominance of peaks compared to BW30.

The roughness parameter results (Table 1) contributed the visual inspection. Among the characterised membranes, the $R_{R M S}$ roughness value for the coated membranes SW30HR $(69.6 \mathrm{~nm})$ and BW30 $(56.5 \mathrm{~nm})$ was somewhat lower in comparison to the uncoated membranes (LE, XLE and NF90). Among the uncoated TFC PA membranes, LE and NF90 had lower surface roughness than XLE. However, the deviation of the roughness values was relatively high, as it can be expected for such a heterogeneous membrane surface. The slightly decreased roughness of the coated BW30 and SW30HR membranes is most likely due to deposition of a very thin coating layer. As can be expected in theory, the additional coating layer fills the valleys of the PA selective layer. The high deviation in roughness may be explained by the uneven deposition of the coating. On the other hand, the uncoated membranes showed similarly the high deviation of the roughness values. This can be explained by the differences in the formation of the PA selective layer, resulting uneven peak-and-valley surface structure.

\subsection{Water Contact Angle and Surface Energy}

Table 1 summarises the results on water contact angle and surface energies with total, polar and dispersive values. The PVA coated membranes (SW3OHR and BW30) had lower water contact angle and higher surface energy values in comparison to uncoated membranes (LE, XLE and NF90). Indeed, the most hydrophilic $\left(27.5^{\circ}\right)$ and highest surface energy $(66.1 \mathrm{mN} / \mathrm{m})$ was measured for SW30HR membrane. In addition, SW3OHR showed the highest polar surface energy value $(24.3 \mathrm{mN} / \mathrm{m})$, among the characterised membranes. BW30 membrane had slightly higher water contact angle $\left(43.1^{\circ}\right)$ and respectively, lower surface energy $(55.9 \mathrm{mN} / \mathrm{m})$. Moreover, the polar surface energy (19.2 $\mathrm{mN} / \mathrm{m}$ ) of BW30 was somewhat lower than SW30HR. Based on the results, the PVA coating increased the polarity of the TFC PA membrane surface.

Among the uncoated TFC PA membranes, LE membrane had clearly the lowest values for water contact angle $\left(53.2^{\circ}\right)$ and respectively, highest for the surface energy $(54.6 \mathrm{mN} / \mathrm{m})$. The surface energy value for LE was almost at the same 
a) SW3OHR

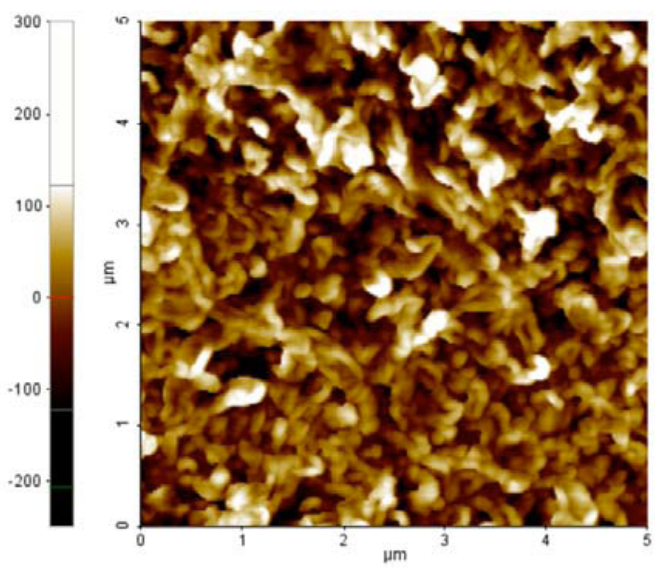

c) LE

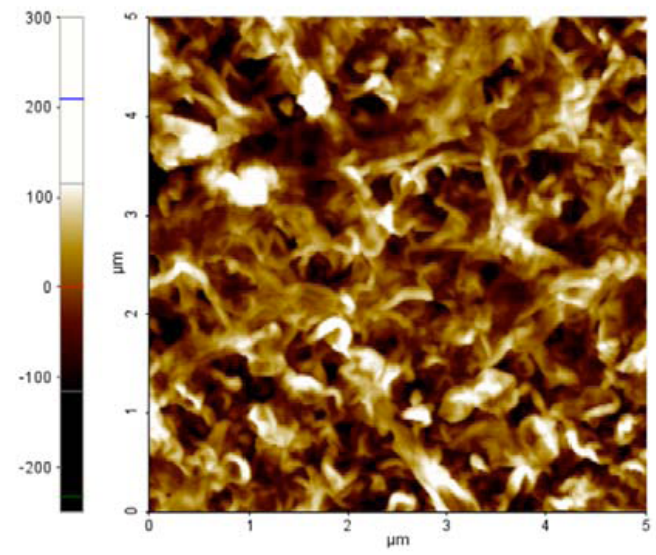

e) NF90

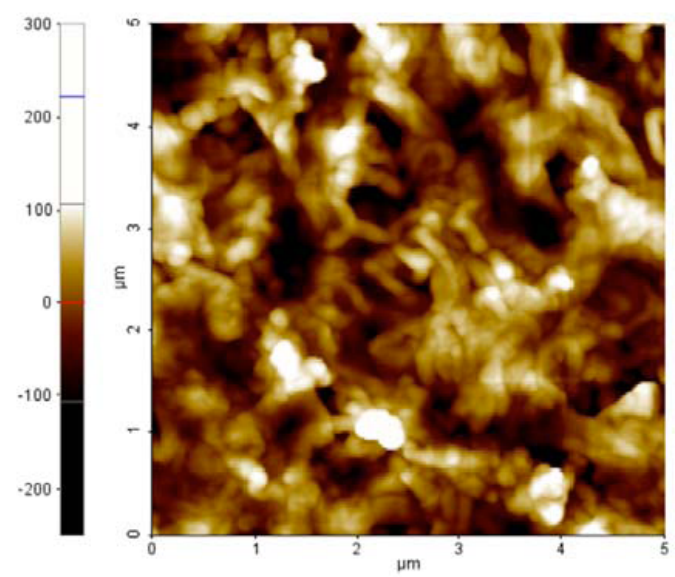

b) BW30

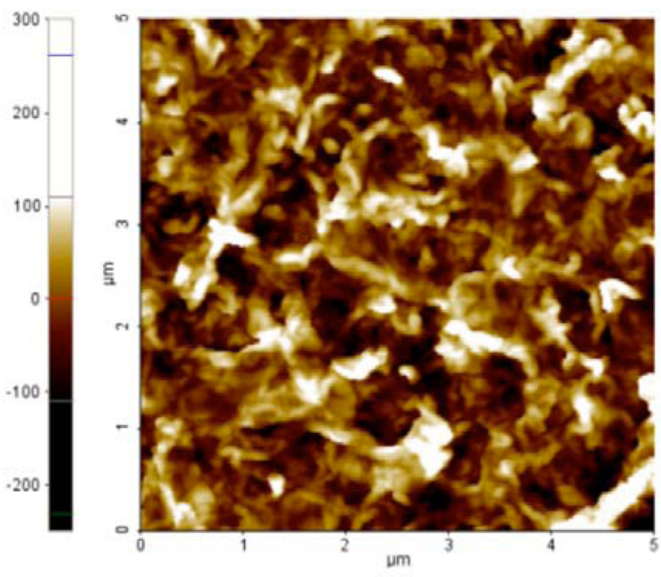

d) XLE

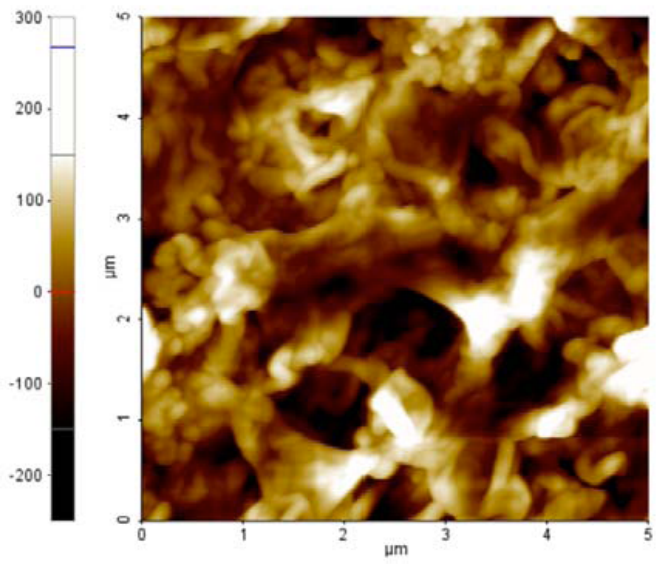

Figure 2: The AFM images of the characterised PA TFC membranes a) SW30HR, b) BW30, c) LE, d) XLE and e) NF90.

level with the coated membranes. However, the comparison of polar surface energy values revealed that LE membrane surface had lower polarity $(11.3 \mathrm{mN} / \mathrm{m})$. In contrast, XLE and NF90 membranes showed most hydrophobic and non-polar surface properties, among the characterised membranes. In fact, the highest value for water contact angle $\left(75.7^{\circ}\right)$ and respectively, the lowest value for surface energy $(37.7 \mathrm{mN} / \mathrm{m})$ were measured for XLE membrane. Similarly, NF90 membrane showed hydrophobic surface properties. NF90 membrane had slightly lower value for water contact angle value $\left(69.9^{\circ}\right)$ and respectively, higher value for surface energy $(42.0 \mathrm{mN} / \mathrm{m})$ in comparison to XLE. However, the polarity of XLE membrane $(3.5 \mathrm{mN} / \mathrm{m})$ was higher compared to NF90 membrane $(1.6 \mathrm{mN} / \mathrm{m})$. 
Table 1: Summary of the Results on Water Contact Angle and Surface Energies

\begin{tabular}{|c|c|c|c|c|c|}
\hline Membrane & $\begin{array}{c}\text { Water contact angle } \\
{[\mathbf{0}]}\end{array}$ & $\begin{array}{c}\text { Total surface energy } \\
{[\mathrm{mN} / \mathrm{m}]}\end{array}$ & $\begin{array}{c}\text { Polar surface energy } \\
{[\mathrm{mN} / \mathrm{m}]}\end{array}$ & $\begin{array}{c}\text { Dispersive surface } \\
\text { energy } \\
{[\mathrm{mN} / \mathbf{m}]}\end{array}$ & $\begin{array}{c}\text { RMS } \\
\text { roughness } \\
{[\mathrm{nm}]}\end{array}$ \\
\hline \hline SW30HR & $27.5 \pm 4.8$ & 66.1 & 24.3 & 31.8 & $69.6 \pm 11.6$ \\
\hline BW30 & $43.1 \pm 4.0$ & 55.9 & 19.2 & 46.7 & $56.5 \pm 4.5$ \\
\hline LE & $53.2 \pm 9.2$ & 54.6 & 11.3 & 34.3 & $75.1 \pm 22.7$ \\
\hline XLE & $75.7 \pm 5.3$ & 37.7 & 3.5 & 40.4 & $95.5 \pm 20.5$ \\
\hline NF90 & $69.9 \pm 3.9$ & 42.0 & 1.6 & & $76.4 \pm 12.3$ \\
\hline
\end{tabular}

\subsection{Bacterial Anti-Adhesion}

Biofouling tendency of the membranes is typically studied by either detecting flux decline or CFU or microscopical analysis of the attached bacteria $[12,15,16]$. The current study analysed attachment of the bacteria after soaking the membranes in the mixture of standard seawater and $P$. aeruginosa. Figure 3 presents the results of the viability analysis of the membrane samples after 24 hour exposure to $P$. aeruginosa. The results are presented as logarithmic CFU value for the detected area $\mathrm{cm}^{2}$.

The attachment of the bacteria was significantly different between the membranes. Indeed, the decrease in the amount of viable cells can be observed simultaneously with the increase of hydrophilicity and surface polarity (see Table 1). The lowest amount of bacteria was attached to the most hydrophilic and polar SW30HR and BW30 membranes. Among the uncoated membranes, LE membrane had somewhat lower amount of attached bacteria in comparison to XLE and NF90 membranes. Indeed, the amount of bacteria found from the surface increased in the order: LE, XLE and NF90.

The correlation between the polar surface energy and the attachment of bacteria was investigated in order to gain further knowledge of the effect of the surface energy on the attachment of bacteria. Apparently, the polar surface energy values correlated clearly with the attachment of the bacteria. The amount of bacteria decreased identically with the increase of polar surface energy value. In addition, the type of the surface roughness may somehow contribute to the bacteria repellence. However, an exact conclusion cannot be presented due to heterogeneous surface topography of the membranes.

\subsection{AFM Interaction Force Curve Measurements}

Figure 4 presents the AFM interaction force curves for the BW30 and NF90 membranes. The result provided complementary knowledge concerning the differences in the attachment of bacteria on the coated and uncoated membrane surfaces. The interaction force value was approximately $0 \mathrm{nN}$ for the coated BW30 membrane. In fact, the coated BW30 membrane showed almost repulsion forces to microsphere tip functionalized with carboxylic groups ($\mathrm{COOH})$. In contrast, NF90 membrane showed strong attraction towards the tip. As indicated previously coated BW30 membrane had more polar and hydrophilic surface compared to NF90 membrane. Therefore, the polar surface of BW30 membrane showed more electrostatic repulsion towards the surface of the tip compared to NF90 membrane. Based on the experiments, it can be expected that BW30 membrane would be more bacteria or foul repellent. The

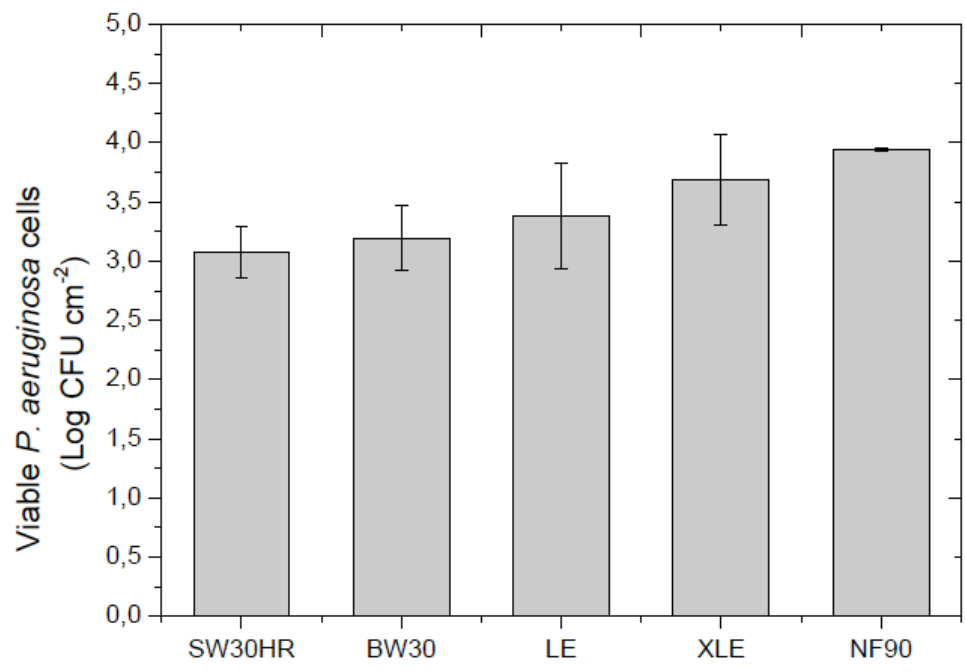

Figure 3: Viable $P$. aeruginosa cells on different membrane surfaces after $24 \mathrm{~h}$ exposure. 


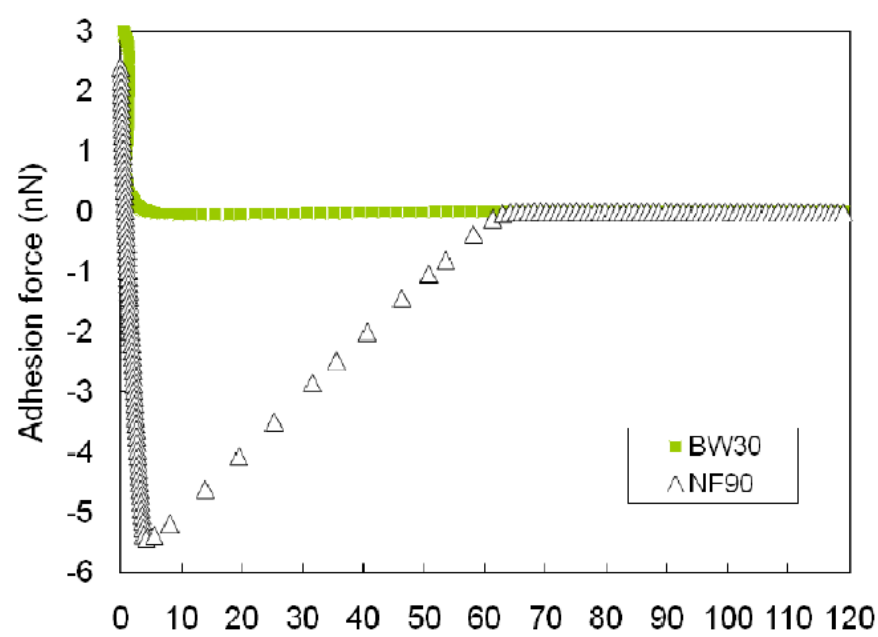

Separation distance (nm)

Figure 4: AFM force curve results for BW30 and NF90 membranes.

observation explains partly the reason for the lower amount of bacteria found from BW30 membrane compared to NF90 membrane.

\section{CONCLUSIONS}

The surface properties of coated and uncoated fully aromatic TFC PA membrane surfaces were systematically characterised using TEM, AFM and contact angle measurements. Among the characterised membranes, the PVA coated TFC PA membranes showed higher hydrophilicity and surface polarity as well as lower surface roughness in comparison to uncoated. The bacteria attachment test showed differences between the coated and the uncoated membranes. The increase in hydrophilicity and surface polarity showed decrease in the attachment of $P$. aeruginosa cells. In fact, surface polarity showed better correlation with bacteria adherence. Moreover, the AFM interaction force measurement demonstrated higher repellence performance for the more polar surface. The amount of bacteria decreased identically with the increase of polar surface energy value. In addition, the type of the surface roughness may somehow contribute to the bacteria repellence. However, an exact conclusion cannot be presented due to heterogeneous surface topography of the membranes. To summarise the main findings, a high polar surface combined with small-size and homogeneous nodular topography could be an optimal surface with the bacterial anti-adhesion performance.

\section{ACKNOWLEDGEMENTS}

The authors acknowledge Tekes (the Finnish Funding Agency for Technology and Innovation) and VTT Technical Research Centre of Finland due to the financial support of project. Skilful technical assistances of Niina Torttila and Sini Eskonniemi are acknowledged in the microbiological part and the contact angle measurements.

\section{REFERENCES}

[1] Al-Ahmad M, Abdul Aleem FA, Mutiri A, Ubaisy A. Biofuoling in RO membrane systems Part 1: Fundamentals and control. Desalination 2000; 132: 173-79.

http://dx.doi.org/10.1016/S0011-9164(00)00146-6

[2] Hemming $\mathrm{H}-\mathrm{C}$. Reverse osmosis membrane biofouling. Exper Thermal Fluid Sci 1997; 14(4): 382-91.

[3] Tang CY, Chong TH, Fane AG. Colloidal interactions and fouling of NF and RO membranes: A review. Adv Colloid Interface Sci 2011; 164(1-2): 126-43

http://dx.doi.org/10.1016/i.cis.2010.10.007

[4] Vrijenhoek EM, Hong S, Elimelech M. Influence of membrane surface properties on initial rate of colloidal fouling of reverse osmosis and nanofiltration membranes. J Membr Sci 2001; 188: 115-28. http://dx.doi.org/10.1016/S0376-7388(01)00376-3

[5] Chen V, Mansouri J, Charlton T. Biofouling in Membrane Systems, In Peinemann K-V, Nunes SP, Membranes for Water Treatment, WileyVCH, Weinheim 2010; vol. 4: pp. 25-48.

[6] Redondo JA. Development and experience with new FILMTEC reverse-osmosis membrane elements for water-treatment. Desalination 1996; 108: 59-66. http://dx.doi.org/10.1016/S0011-9164(97)00009-X

[7] Tang CY, Kwon Y-N, Leckie JO. Effect of membrane chemistry and coating layer on physiochemical properties of thin film composite polyamide RO and NF membranes: I. FTIR and XPS characterization of polyamide and coating layer chemistry. Desalination 2009; 242 : 149-67.

http://dx.doi.org/10.1016/j.desal.2008.04.003

[8] Tang CY, Kwon Y-N, Leckie JO. Effect of membrane chemistry and coating layer on physiochemical properties of thin film composite polyamide RO and NF membranes II. Membrane physiochemical properties and their dependence on polyamide and coating layers. Desalination 2009; 242: 168-82.

http://dx.doi.org/10.1016/i.desal.2008.04.004

[9] Tang CY, Kwon Y-N, Leckie JO. Fouling of reverse osmosis and nanofiltration membranes by humic acid - Effects of solution composition and hydrodynamic conditions. J Membr Sci 2007; 290: 86-94.

http://dx.doi.org/10.1016/i.memsci.2006.12.017

[10] Wang YN, Tang CY. Protein fouling of nanofiltration, reverse osmosis and ultrafiltration membranes - The role of hydrodynamic conditions, solution chemistry, and membrane properties. J Membr Sci 2011; 376: $275-82$.

http://dx.doi.org/10.1016/i.memsci.2011.04.036

[11] Norberg D, Hong S, Taylor J, Zhao Y. Surface characterization and performance evaluation of commercial fouling resistant low-pressure RO membranes. Desalination 2007; 202: 45-52.

http://dx.doi.org/10.1016/j.desal.2005.12.037 
[12] Herzberg M, Elimelech M. Biofouling of reverse osmosis membranes: Role of biofilm-enhanced osmotic pressure. J Membr Sci 2007; 295: $11-20$

http://dx.doi.org/10.1016/..memsci.2007.02.024

[13] Klausen $M$, Heydorn $A$, Ragas $P$, et al. Biofilm formation by Pseudomonas aeruginosa wild type, flagella and type IV pili mutants. Mol Microbiol 2003; 486: 1511-24. http://dx.doi.org/10.1046/i.1365-2958.2003.03525.x

[14] Flemming H-C, Wingender J. The biofilm matrix. Nat Rev Microbiol 2010; 8: 623-33.

[15] Sadr Ghayeni SB, Beatson PJ, Schneider RP, Fane AG. Adhesion of waste water bacteria to reverse osmosis membranes. J Membr Sci 1998; 138: 29-42.

http://dx.doi.org/10.1016/S0376-7388(97)00196-8

[16] Subramani A, Hoek EMV. Biofilm formation, cleaning, re-formation on polyamide composite membranes. Desalination 2010; 257: 73-79. http://dx.doi.org/10.1016/i.desal.2010.03.003

[17] Kang S, Hoek EMV, Choi H, Shin H. Effect of membrane surface properties during the fast evaluation of cell attachment. Sep Sci Technol 2006; 41: 1475-87. http://dx.doi.org/10.1080/01496390600634673

[18] Khan MMT, Stewart PS, Moll DJ, Mickols WE, Nelson SE, Camper AK. Characterization and effect of biofouling on polyamide reverse osmosis and nanofiltration membrane surfaces. Biofouling 2011; 272: 173-83.

http://dx.doi.org/10.1080/08927014.2010.551766

[19] Rana D, Matsuura T. Surface Modifications for Antifouling Membranes. Chem Rev 2010; 110: 2448-71. http://dx.doi.org/10.1021/cr800208y

[20] Tang CY, Fu QS, Robertson AP, Criddle CS, Leckie JO. Use of reverse osmosis membranes to remove perfluorooctane sulfonate
(PFOS) from semiconductor wastewater. Environ Sci Technol 2006; 40: 7343-49. http://dx.doi.org/10.1021/es060831q

[21] Grundke K. Characterization of Polymer Surfaces by Wetting and Electrokinetic Measurements - Contact Angle, Interfacial Tension, Zeta Potential, In: Stamn M. Polymer Surfaces and Interfaces Characterization, modification and Applications, $1^{\text {st }}$ ed. SpringerVerlag Berlin Heidelberg 2008; pp. 103-136. http://dx.doi.org/10.1007/978-3-540-73865-7 6

[22] Tang CY, Kwon Y-N, Leckie JO. The role of foulant-foulant electrostatic interaction on limiting flux for RO and NF membranes during humic acid fouling-Theoretical basis, experimental evidence, and AFM interaction force measurement. J Membr Sci 2009; 326: 526-32.

http://dx.doi.org/10.1016/i.memsci.2008.10.043

[23] Li Q, Elimelech M. Organic fouling and chemical cleaning of nanofiltration membranes: Measurements and mechanisms. Environ Sci Technol 2004; 38: 4683-93 http://dx.doi.org/10.1021/es0354162

[24] Khulbe KC, Feng CY, Matsuura T. Synthetic polymeric membranes characterisation by atomic force microscopy. Springer-Verlag Berlin Heidelberg 2008; pp. 157-167.

[25] D1141-98 Standard Practise for the Preparation of Substitute Ocean Water 2008.

[26] Tang CY, Kwon Y-N, Leckie JO. Probing the nano- and micro-scales of reverse osmosis membranes-A comprehensive characterization of physiochemical properties of uncoated and coated membranes by XPS, TEM, ATR-FTIR, and streaming potential measurements. J Membr Sci 2007; 287: 146-56.

http://dx.doi.org/10.1016/i.memsci.2006.10.038 